\title{
Perspectives on the History of Ancient Near Eastern Studies: An Introduction
}

\author{
Lorenzo Verderame and Agnès Garcia-Ventura
}

From January to May 2016 the editors of the present volume organized at "Sapienza," Università degli Studi di Roma, a series of lectures and workshops under the title Storia degli studi sul Vicino Oriente Antico. ${ }^{1}$ In that occasion we used "storia degli studi" in a broad sense, as a label encompassing a myriad of perspectives and topics of study, sharing as common denominator a reflexive approach toward the study of the past and, more specifically in our case, the study of the ancient Near East.

As a result of this broad scope, the series included about thirty lectures and presentations dealing with four main topics: first, the reception of the ancient Near East in popular culture; second, the reconstruction of the Near Eastern past through archaeology; third, the historiography of ancient Near Eastern studies; fourth and last, approaches to intellectual history through a selection of issues and topics most commonly discussed in ancient Near Eastern studies. The essays dealing with the first and second topics, those linked to the so-called reception studies, have been collected and edited by the present writers in the volume Receptions of the Ancient Near East in Popular Culture and Beyond. ${ }^{2}$ Those dealing with the third and fourth topic, those linked with the history of ancient Near Eastern studies, are the ones collected and edited in the present volume. Before summarizing the structure and content of the book, a few words are in order about how we understand the relationship between historiography and intellectual history, as well as about the way the diverse authors approach their topics of study in this collection of essays.

As mentioned above, the common denominator of "storia degli studi" understood in a broad sense is the reflexive approach to the disciplines and to the research devoted to the study of the past. This reflexive approach includes what we may define as several research branches or even, in some cases, as several stages of the same (at least potentially) research perspectives. On the one hand, there is the research about the history of a given academic discipline. This research, at least in its first stages, has a more descriptive character, as it aims at collecting the basic data about who developed certain studies, and about the years, conditions, and institutions in which this research was developed. This first descriptive approach is often devoted to the reconstruction of the way a discipline, ancient Near Eastern studies in our case, has been founded

I. The initiative has been funded by a grant program organized at "Sapienza" Università degli Studi di Roma ("Giornate di storia degli studi sul Vicino Oriente Antico"; C26Ci57SL3). For a detailed program with titles and participants, see http://lorenzoverderame.site.uniromar.it/attivita-I/20I6storiastudi (accessed I5 September 20I8).

2. Verderame and Garcia-Ventura 2020. 
and developed in a specific country or in a specific academic tradition. In this direction there is a quite long tradition of research, carried on since the first decades of the twentieth century in the Great Britain, France, and Germany. ${ }^{3}$ Solid proof of this early interest in historiography was the publication in 1904 of C. Fossey's Manuel d'assyriologie, or the monograph by E. A. Wallis Budge, Rise and Progress of the Assyriology (1925).

On the other hand, another branch or stage of the research, often following the previous one, has an eminently analytical character. This branch is included as well within the "storia degli studi" we used as framework for our series of seminars, even though it is distinct from the more descriptive research just reported and is often labelled as "storia delle idee" or "intellectual history" in the English-speaking traditions. Intellectual history can take as its framework a specific country or a specific academic tradition, as the more descriptive historiography usually does. When it happens, this research may work as a synthesis of the previous descriptive work as it often takes as a starting point this previous collection of data. In other cases, intellectual history does not restrict analysis to the research produced in a specific territory, but it develops it, taking into account a transnational point of view that aims at identifying the Zeitgeist shared by contemporary researchers who do necessarily share the same academic tradition. A good example of this line of research is the one developed by Mario Liverani, as can be seen in his collection of essays translated into English and published in 2004 under the title Myth and Politics in Ancient Near Eastern Historiography. All in all, despite the differences between intellectual history ("storia delle idee") and the more descriptive histories of the specific disciplines ("storia degli studi" in a strict sense), we decided to include both in the same volume, thus considering both as complementary one to the other. As a consequence of this choice, in this volume we present together elaborate analytical approaches to topics recurring in ancient Near Eastern studies, as well as descriptive essays laying the foundation for further analyses in countries and academic traditions never considered as research topics up to this point.

The volume you have in your hands brings together eighteen essays dealing with the history of ancient Near Eastern studies, understood in this broad sense previously described. Preliminary versions of six of the essays were presented at the seminars held in Rome in 20I6, ${ }^{4}$ and they are offered here alongside papers from other guest contributors. Among the authors there are colleagues who have been dealing with historiography and intellectual history as one of their main lines of research in recent years, while others kindly accepted our invitation to contribute to the volume, giving us the possibility to include first hand studies from academic traditions, like Chinese or Portuguese ancient Near Eastern studies, not common in the historiographical debates. To all of them we owe gratitude for their willingness to cooperate and to be part of this editorial project.

3. On this early interest of ancient Near Eastern scholars to reflect on the discipline and on their own careers, see, among others, Vita 20I2. However, despite this early interest, there is also a clear lack of tradition of historiographical research in our field of study. For some thoughts in this direction and discussion of previous publications, see Vidal 2015.

4. These are the essays by the following authors (by alphabetical order): Silvia Alaura, Eva von Dassow, Sebastian Fink, Pietro Giammellaro, Ahmed Fatima Kzzo, and Jordi Vidal. 
The eighteen essays are grouped in four sections, preceded by this introductory chapter, each section being an example of the different possible developments of the study of the history of our discipline. The first section, titled "The Edge of the Abyss: The Study of Antiquity Under Totalitarian Threat," includes the chapters by Silvia Alaura, Sebastian Fink, Jakob Flygare, Pietro Giammellaro, Patrick Maxime Michel, and Luděk Vacín and Jitka Sýkorová, who co-author their contribution. All these contributions have in common, on the one hand, the chronological framework chosen, that is the first half of the twentieth century CE roughly speaking. On the other hand, they have in common the particular attention devoted to the way the political context affects and shapes research. In this case, they discuss the influence totalitarian regimes and wars had on the way the discipline was taught and developed, but also commenting on the way material culture was managed and displayed. The essays included in this section cover a rich array of territories (Italy, Germany, UK, current Czech Republic, and Syria), as well as some of the most outstanding characters of ancient Near Eastern studies such as Albrecht Goetze, Hans Gustav Güterbock, Benno Landsberger, Wolfram von Soden, and Leonard Woolley. Moreover, it is worth highlighting the richness of the specialties discussed in these essays, including Hittitology and Phoenician studies, among others, offering a picture more varied than the usual one, which often restricts the debates to ancient Mesopotamian sources.

The second section, titled "Intellectual History and Ancient Near Eastern Studies: Some Case Studies," includes the chapters by Carlos Gonçalves, Emanuel Pfoh, and Eva von Dassow. They discuss concepts and research topics as complex as mathematics, feudalism, ethnic identity, and nation-building. Each topic is approached from a broad chronological perspective, which traces in all cases the course of their use throughout the history of ancient Near Eastern studies. Unlike the previous section, these chapters do not circumscribe themselves to a specific chronology or to a specific country but try to see through diachronic analysis how certain topics and concepts have been discussed in the discipline and how in each case the cultural and the social context potentially influenced research.

The third section, titled "From our Stories to the History of Ancient Near Eastern Studies," includes the chapters by Selim Ferruh Adalı and Hakan Erol (a joint contribution), Isabel Almeida, Petr Charvát, Katrien De Graef, Parsa Daneshmand, Changyu Liu, and Jordi Vidal. This section is devoted to the history of the discipline in diverse geographical areas, focusing on academic traditions in ancient Near Eastern studies only seldomly considered as topics of study, or even as territories never before considered as such. All of them, then, aim to lay the foundations for future research on the history of ancient Near Eastern studies in academic traditions often considered "peripheral" in the field of study. In this section the following territories are considered (listed following the chapter order): Turkey, Portugal, the Czech-speaking lands, Belgium, Iran, China, and Spain. All of them are authored by colleagues who developed (or are still developing) their research in these countries and, in some cases, they offer the reader firsthand data about the development of the discipline there. However, while some of them offer a panoramic view result of the work with archival materials, others are examples of oral history.

The fourth and last section of the present volume is titled "Current Prospectives, Future Perspectives," and it includes the chapters authored by Steven W. Holloway 
and Ahmed Fatima Kzzo. As we tried to convey with the title, these two chapters offer not only a glance into the past, but especially a glance into the way this past may influence or may be studied in the future. The potential of internet resources, heritage management, and schoolbooks are main features discussed here as tools which mediate between the past and us, but also as tools which transform the past itself and its reception thanks to this mediation.

The final editing of the volume was completed during the burst of the COVID-I9 pandemic. The editors would like to thank both the authors and the Pennsylvania State University Press's project manager, Matthew Williams, for keeping pace with the circumstances. Without their effort, we could not complete the present volume.

\section{REFERENCES}

Budge, E. A. W. 1925. The Rise and Progress of Assyriology. London: M. Hopkinson \& Co. Fossey, C. 1904. Manuel d'assyriologie. Paris: Ernest Leroux.

Liverani, M. 2004. Myth and Politics in Ancient Near Eastern Historiography. Sheffield: Equinox.

Verderame, L., and A. Garcia-Ventura. 2020. Receptions of the Ancient Near East in Popular Culture and Beyond. Atlanta: Lockwood Press.

Vidal, J. 20I5. "Reflexiones historiográficas sobre el Orientalismo Antiguo." Pages 25-36 in Descubriendo el Antiguo Oriente. Pioneros y arqueólogos de Mesopotamia y Egipto a finales del s. XIX y principios del s. XX. Edited by R. Da Riva and J. Vidal. Barcelona: Bellaterra arqueología.

Vita, J.-P. 20I2. "La Asiriología según los asiriólogos." Cadmo. Revista de História Antiga 22:9-I8. 